\title{
References
}

1. Peleshchyshyn, A.M. \& Tymovchak-Maksymets, O.Yu. (2010) Analysis of communicative interaction of community Web forums. Skhidno-levropeiskyi zhurnal peredovykh technologiy, 6/8, 44-49 [in Ukrainian].

2. Peleshchyshyn, A.M. \& Korzh, R.O. \& Guminskyi, R.V. (2014) Definition of recommendations for informational impact on the structure of the virtual community. Bezpeka informatsii: Scientific and Practical magazine, 3, 264-273 [in Ukrainian].

3. Peleshchyshyn, A.M. \& Guminskyi, R.V. (2013) The threats of state information security in social networks. Nauka I tekhnika Povitryanych syl Zbroynych Syl Ukrainy: Scientific and Technical magazine, 2(11), 192-199 [in Ukrainian].

4. Peleshchyshyn, A.M. \& Peroganych, Yu.Y. (2009) Formation of public authority of universities through the online encyclopedia Wikipedia. Computer Science and Information Technology: Proceedings of the 4th International Scientific and Technical Conference CSIT-2009 (pp. 31-33) Lviv: PP «Vezha i Ko» [in Ukrainian].

5. Forkun, Yu.V. (2012) Methodology for evaluating the activities of developers of information and reference support for public communication systems. Technologichnyi audyt ta reservy vyrobnytstva. (Vol. 4), 6/4, 45-46 [in Ukrainian].

6. Forkun, Yu.V. \& Peleshchyshyn, A.M. (2012) Modern approaches to technology development and formation of information support for public communication systems. Skhidno-levropeiskyi zhurnal peredovykh technologiy, 2/2(56), 3-12 [in Ukrainian].

7. Aibar, E. \& Lladós-Masllorens, J. \& Meseguer-Artola, A. \& Minguillón, J. \& Lerga, M. (2015). Wikipedia at university: what faculty think and do about it. The Electronic Library, 33(4), 668-683.

8. Delanty, G. (2003) Ideologies of the Knowledge Society and the Cultural Contradictions of Higher Education . Policy Futures in Education. (Vol. 1.), 1, (pp. 71-82).

9. Evenstein Sigalov, S. \& Nachmias, R. (2017) Wikipedia as a platform for impactful learning: A new course model in higher education Education and Information Technologies 22: 2959. https://doi.org/10.1007/s10639-016-9564-z

10. Howard, T. (2015) Design to Thrive: Creating Social Networks and Online Communities that Last; 1st Edition. Elsevier, 225

Стаття надійшла до редакції 19.06.2018 p.

УДк 008:379.8

\author{
Petrova Iryna \\ D.Sc. in Cultural studies, \\ Professor of Event Management \\ and Leisure Industry Department, \\ Kyiv National University of Culture and Arts \\ ORCID 0000-0002-8146-9200 \\ petrovaiw@gmail.com
}

\section{PECULIARITIES OF FORMATION OF THE LEISURE ACTIVITY SPHERE IN UKRAINE OF THE 20-30IES OF THE XX CENTURY}

The purpose of the research lies in the justification of peculiarities and tendencies of development of leisure field in Ukraine of the 1920-1930ies of the XXth century. The methodology of the study lies in applying of methods of analysis, synthesis, and generalization and using of terminological, historical and culturally approaches that allowed to reveal and justify the peculiarities of forming of leisure in the 1920-1930ies of the XXth century. The scientific novelty lies in that at the first time in the domestic study of culture it was made an effort to classify the directions of leisure activity of this period and present the ways of forming of "Soviet" model of leisure. It was analyzed the political and educational, cultural, antireligious, scientific, methodical and creative directions of leisure activity, characterized the principles, forms, and functions of leisure activity in determined years. Conclusions. It was proved that infrastructure of leisure in the 1920-1930ies of the XXth century comprises different kind of establishments: clubs, national houses, reading-houses, cultural and educational groups, houses and palaces of culture that became free for charge and available. The mass events with ideological, political and educational character are directed on all kind of population. For achieving the tasks defined by the Soviet government, it was organized systematic training of staff for culture and leisure establishments, and new forms and methods of work enriched leisure activity.

Key words: leisure, policy, political and educational forms, Soviet Ukraine, ideology, clubs.

Петрова Ірина Владиславівна, доктор культурології, профресор, профресор кафедри івентменеджменту та індустрії дозвілля Київського національного університету культури і мистецтв

Особливості формування сфери дозвілля в Україні 20-30-х років XX ст.

Метою дослідження $є$ обґрунтування особливостей і тенденцій розвитку сфери дозвілля в Україні у 2030-ті pp. XX ст. Методологія дослідження полягає у застосуванні методів синтезу, аналізу, узагальнення, а також у використанні термінологічного, історичного та культурологічного підходів, що дозволило виявити та обґрунтувати особливості формування дозвілля у 20-30 рp. XX ст. Наукова новизна полягає у тому, що у вітчизняній культурології вперше здійснено спробу класифікувати напрями дозвіллєвої діяльності цього періоду й показати шляхи формування "радянської" моделі дозвілля. Проаналізовано політико-просвітній, культурний, антирелігій- 
ний, науково-методичний та творчий напрями дозвіллєвої діяльності, охарактеризовано принципи, форми та функції дозвіллєвої діяльності означуваних років. Висновок. Доведено, що інфраструктура дозвілля 20-30-х рр. XX ст. охоплює різні види установ: клуби, народні будинки, хати-читальні, культурно-просвітні гуртки, будинки та палаци культури, які стали безкоштовними та доступними. Масові заходи, що мають ідеологічно спрямований та політико-просвітній характер, спрямовані на усі верстви населення. Задля досягнення встановлених радянською владою завдань налагоджено систематичну підготовку кадрів для закладів культури й дозвілля, а саму дозвіллєву діяльність збагачено новими формами та методами роботи.

Ключові слова: дозвілля, політика, політико-просвітні форми, Радянська Україна, ідеологія, клуби.

Петрова Ирина Владиславовна, доктор культурологии, профрессор, профрессор кафедры ивентменеджмента и индустрии досуга Киевского национального университета культуры и искусств

Особенности формирования сфреры досуга в Украине 20-30-х годов XX ст.

Целью исследования является обоснование особенностей и тенденций развития сферы досуга в Украине в 20-30-е гг. XX ст. Методология исследования заключается в применении методов синтеза, анализа, обобщения, а также в использовании терминологического, исторического и культурологического подходов, что позволило выявить и обосновать особенности формирования досуга этого периода. Научная новизна заключается в том, что в отечественной культурологии впервые предпринято попытку классифицировать направления досуговой деятельности этого периода и показать пути формирования «советской» модели досуга. Проанализированы политико-просветительной, культурный, антирелигиозный, научно-методический и творческий направления досуговой деятельности, охарактеризованы принципы, формы и функции досуговой деятельности этих лет. Вывод. Доказано, что инфраструктура досуга 20-30-х гг. XX в. охватывает различные виды учреждений: клубы, народные дома, избы-читальни, культурно-просветительные кружки, дворцы культуры, которые стали бесплатными и доступными. Массовые мероприятия, имеющие идеологически направлен и политико-просветительной характер, направлены на все слои населения. Для достижения установленных советской властью задач налажено систематическое подготовку кадров для учреждений культуры и досуга, а саму досуговая деятельность обогащен новыми формами и методами работы.

Ключевые слова: досуг, политика, политико-просветительные формы, Советская Украина, идеология, клубы.

The topicality of the research. The period of the 1920-1930ies of the $X X^{\text {th }}$ century is one of the contradictory periods in the history of leisure activity sphere. It is characterized by remarkable achievements and great estimations, the development of the leisure initiatives of the population assisted with high ideologization and political booking of culture institutions, popularization of democratic and amateurs' activities in the leisure activities' organizations, and at the same time, centralization and control of their work in real life, propagandized by the systemic of cultural, educational and leisure activities and their instability, demonstration and excessive organization.

The state of a scientific development of the problem. The historical aspects of the leisure activities are being worked out by such scientists as T. Kisel'ova, S. Pinalov, O. Sasihov, Yu. Chernyavskyi and others. Though the domestic science lacks the works in which there is disclosed the development of the leisure activity sphere in the Soviet Ukraine at the first decade after the Socialist Revolution that makes certain difficulties for the objective analysis and estimation of the formation of leisure activities at this period. That's why the aim of our article is to give grounds of the peculiarities and tendencies of the development of the leisure activity sphere in Ukraine in the 20-30ies of the $X X^{\text {th }}$ century.

The exposition of the basic material. To give a brief outline of the specificity of the functioning of the leisure activity sphere of the denoted years, it is necessary to mark the expediency of the classification of the trends of the leisure activity of this period onto the political, educational, cultural, antireligious, scientific, methodological and creative.

Particularly, the main aim of the political and educational forms of the leisure activity is to eliminate the illiteracy among the adult population, his political education. Organizational and coordinative center of the political and educational work becomes the Department of the extracurricular education, which was organized at the people's Commissariat, and later reorganized into Political and Educational Committee of Ukraine.

Soviet government forms voluntary republican society named after V. Lenin "Away off the illiteracy!" (1923), the network of schools for adults, center of liquidation of illiteracy, national universities, cultural and educational societies. So, there were actively working approximately 1 thousand of schools for illiterated people in Ukraine in 1927, more than 100 courses for workers and peasants, 10 national universities. The basic principle of education of grown-up people is announced in the principle of unity of general education with political education. The struggle with illiteracy and ignorance is defined as a main task of the soviet authorities. Though, inspite of great forces, which were aimed at the solution of this task, information of the kind "there introduced the obligatory education of all uneducated Red Army soldiers. As a result of the great work the whole staff of the Red Army was literate till the $1^{\text {st }}$ of May 1922"; there were no illiterated among young communists at the end of the 1920" $[3,73]$, can hardly be called trustworthy. As S. Siropolko writes: "the statement about the absolute liquidation of illiteracy onto the territory of the Soviet Ukraine was only a declaration, and in reality there was a breach onto this front: "We have 1200 thousand illiterated men that were left for the second five-year plan in Ukraine" $[7,83]$. 
Moreover, the obligatory education was neither completely obligatory nor free of charge, and considerable amount of adults, who didn't finish courses of liquidation of illiteracy, had such knowledge resource that for a short period of time were removed to the category of illiterated. That's why it's not a surprise there were accepted once again the decree about the measures as for the permanent liquidation of illiteracy among adults in 1937.

The aim of the cultural approach to the leisure activities became the improvement of cultural level of the population. The most effective form of the work, that was accepted, was mass cultural outings, which started with the initiative of the young communists at the end of the 20ies of the XX century. In the course of time cultural outings were aimed at not only improvement but also at the solution of financial, personnel, technical questions (buying books, musical instruments, repairing of offices, organization of courses for clubworkers etc.). Nationalization had a considerable meaning as well, the protection of the cultural memorials and values, their openness and general accessibility and the following documents favoured this (the Decree about cultural and natural memorials of Ukraine, 1926; the Decision about the appropriation to the Opera Theaters in Kiyv, Odesa and Kharkiv got the name of state and academic, 1926; the Decree about the appreciation of the Kiyv-Pecherskaya Lavra the historical and cultural state reservation and reorganization it into All-Ukrainian museum place, 1928; the formation of the state reservation "Sofiivka", 1929 and so on).

This period in the sphere of leisure activities is remarkable with the development of scientific and methodological work: congresses, conferences, meetings, seminars, disputes, the issues of the repertory bulletins, methodological literature, instructors' bulletins. Systematic issue of scientific and methodological literature aims at the arrangement and improvement the leisure activity work. Particularly, the issues of "Club Work. Practical Encyclopedia for Retraining Club Workers" consider the role of a woman in club, forms of club work, principals, methods and peculiarities of her behavior (Issue № 2 "Woman and Club"); the attention is being given to the peculiarities of the club work with different levels of the population and methods of attraction a person to the club (Issue № 3 "Working club, its tasks and basic directives"); the priority of choosing club forms while compiling club plans are being disclosed, there are being analyzed the possibilities of the club (time resources, means, staff, premises), there are being identified its basic tasks and trends of work (Issue № 4, "The context and plan of the club work"); there are being revealed the correlation of the club with the trade unions and industrial organizations, the context and methods of cooperation, organizational forms (Issue № 5, "Trade Union Organizations, manufacture and club"); there are being explained the fundamental principles of the club as a public organization and the basis of the management of the club (Issue № 6 "Club self-government").

A constituent part of the leisure activity institutions is amateur performances and folklore. Theatrical groups dominate among creative clubs and creative studios in 20ies of the XX century, amateur performances enrich with dramatic, choir, musical and dancing groups in the 30ies. So, there took part 20 thousand people in regional Olympiads in Ukraine in 1935, there was held the First Republican Olympiad of amateur art among workers and collective farmers of Ukraine in 1936. The management of the amateur art is done by the central and regional stations of amateur art up to the 1939. They are being reorganized into Central republican and regional houses of folk art.

As for the antireligious propaganda it is realized by means of formation of antireligious groups not only in the houses of culture and leisure activities but at schools as well with the aim "to involve children into the struggle with those who believe in God, to sow discord in the family between children and parents and by any means to inculcate children materialistic outlook" [7, 76]. The effective form of the organization of the antireligious propaganda become groups, mobile antireligious expositions, lections, disputes, discussions.

The basic forms of the leisure activity work of this period are the collective reading, oral newspapers, political games, agitation storms, industrial exhibitions, evenings of the best workers, evenings of questions and answers, contests, meetings with scientists, concert-meetings, performance-meetings, excursions to the enterprises. As we can see, the context of the leisure activity work reflected political, economical, social, cultural life of the country. The principal institutions of the this period were libraries, club foundations (clubs, folk houses, country houses, red corners, reading houses etc.), mobile foundations of culture ("clubs of wheels", mobile libraries, agitation trains), parks of culture and recreation.

A very important element in the development of the cultural and educational work is libraries, which became free and accessible. There were being renovated four types of libraries according to the decree "As for the Centralization of the Libraries" in 1920, which were a part of the unitary library network: central, province, regional, district, mobile or the library at the reading-room. There were numbered more than 4500 libraries in the middle of the 20ies of the XX century in Ukraine.

As a result of closing "Prosvit" (there were more than 4000) in 1925, there appear a great number of country-houses that had to become centers of the political and educational propaganda in the countryside. "Prosvits" were liquidating by the communists as organizations which were related with nationalists and counterrevolution, meanwhile the soviet government "made countryside-houses" entrusting with them as well other institutions of extracurricular education, tasks of the political education in communistic manner. Namely this term "extracurricular education" is changed onto the "political education" [7, 82]. The first country-house was opened in Kharkiv in 1920, likely in Kyiv, Odesa, Zhitomir. The Soviet government stresses onto the point that according to the organizational principle the manager of the country-house is appointed by the de- 
partment of the education, but the elected Board, that is country-house is a public institution of the club type. There begins the demonstration of cinemas in the country-houses since 1924: so, 22 cinema halls are opened in Donbass, 25 - in Kyiv and Kharkiv regions.

Country-houses were reorganized into the collective houses at the beginning of the 30ies, their task was to provide consulting and reference work, to realize antireligious propaganda, to organize mobile exhibitions and cultural and educational activities. There were functioning more than 12 thousand collective houses $[3,149]$.

The active cultural and educational work fulfill reading-houses at the end of the 20ies, which were reorganized into the houses of the socialist culture, houses of countrymen, houses of collectivists, and lately into the palaces and houses of culture, parks of culture and recreation. So, there are being organized reports, lectures, evenings of questions and answers in the reading-houses, there are also being organized political and educational, dramatic, agricultural hobby groups, sections for the liquidation of illiteracy. In fact, reading-houses perform the role of the cultural center in countryside places.

A considerable role in the organization of the leisure activities of the population of this period play mobile cultural and educational institutions: clubs, libraries, agitation trains etc. Their mission was to serve the population which doesn't have the access to the cultural institutions and the possibility to visit them. That's why mobile institutions organize leisure activities in the countryside, at the factories, in hostels among season and agricultural workers. There are being organized concerts, cinema séances, meetings with famous men of different spheres, book exhibitions, informational and reference work, consultations. Different hobby groups gained an outstanding popularity, among them the effective forms were considered the holidays of harvest, agricultural exhibitions, agricultural conferences, agricultural courts, disputes. Mass fests, exhibitions, lectures, readings are held in the parks of culture and recreation, which were being opened in Kyiv, Odesa, Dnipropetrovsk and other Ukrainian places at this time.

Thus, a guiding role in the system of the leisure activity institutions of this period was played by the clubs, which "had only to organize a reasonable rest-time of the workers, but they had to be the centers of the educational work" $[3,76]$. The responsibility was put onto the party organizations for the arrangement of the club work, communists were being sent to work as experienced political workers. There was implemented the position of the regional inspector in the countryside clubs, reading-houses and reading corners in the countries with the aim of coordinating the club work.

The majority of the clubs were leaded by the trade unions, who supported and financed them. Not once there were discussed the questions of "cultural building" of the club at the congress. Among the reasons, that held in the active work of the club with the people, as experts of this period put it, were: the administrative pressure and the practice of obligations, methods of command and bureaucratic regulation of the club life, personal regulation of the club work (meaning the replacement of self-administration with the appointed manager of the club); there were not appreciated wishes and necessities of the members of the club, systematic service by the clubs different political campaigns; loading the members of the club with the work that wasn't interested to them and in case they didn't want to do it they were threatened to be excluded from the club. That is, "the danger of converting the club into the school of political literacy, with the exclusion the elements of entertainment from it, converting the club into the church where there were no songs and jokes, everything this will push away an adult worker from the club in future. The club isn't a school and the leaders of the mass and club work are not teachers. These leaders should be senior colleagues, performing the work onto the basis of amateur performances and voluntary desire of the members of the club themselves" [5, 9].

To avoid the disadvantages marked, it is recommended to organize the work of the club onto the principals of:

- self-government and voluntariness, and not to choose the club managing among the representatives of different organizations, appointing the head manager of the club;

- the attraction of the club that provided making consequent conditions for its visitors;

- amateur performances and initiatives of the club visitors, but not "forced" activity and obligations;

- consideration of the necessities of the club visitors, but not direct banning the interests, which to the club manager's opinion, damaged a grown-up person;

- organization of the entertaining and recreation activity in the clubs, but not just the repletion the club work with political and productive sence;

- creating diversity of the group work, but not artificial arrangement of the groups.

The improvement and detailed revision required planning of the club work. The representatives of the trade unions marked that club should be used basically as a political center, which take an active part in all state and political events: "Without mentioning big political campaigns and revolutionary holidays such as October Revolution, the $9^{\text {th }}$ of January and Lenin's date of death, the Red Army Day, the Worker Day, Paris commune, the $1^{\text {st }}$ of May etc., which made the club to prepare with an exceptional energy and seriousness, involving the whole club assets into the work and all club groups, - the club had to organize a lot of numerous other campaigns: the Air Fleet Day, the Good Chemist's Day, the week of liquidating of the illiteracy, the campaign of prisoners' assistance, the evening dedicated to the aid of German workers and their children, the evening dedicated to homeless children, disabled people, chief's holidays, labour heroes, campaigns 
dedicated to the increasing the labour productivity, to subscription to peasant loan, to all calendar revolutionary fests etc" [5, 21].

The sense of the political and educational work of the club at this period could possibly be divided onto the following trends: propaganda of Leninism that was done in the groups of the political literacy, Lenin's corners via conversations, reports, lectures, live newspapers, stages etc.; propaganda of trade union movement that was aimed popularization and explication of basic tasks of the trade unions, rights and responsibilities of their members, achievements of the work of the trade unions (the protection of economic interests work, increasing of the salary, labour protection etc.); industrial brining up that is realized via reports onto industrial topics, talks, lectures, industrial exhibitions, excursions to the production places.

Negative influence onto the club work was made by the excessive control of the culture commissions, which were formed at factories and plants. The members of the culture commissions weren't chosen but were appointed and preoccupied mostly with the liquidation of the illiteracy onto the enterprise, organization of the advanced training courses, dispatching to the faculties of the proletarian youth, rigid control of the club activity [5, 31].

At last as the result of this "fight" between trade unions and party body there were defined and concretized basic tasks of the trade unions clubs, to which belonged: propaganda of political decisions, the fight for the strengthening of the labour discipline and increasing of production, "communistic upbringing" of the person, amateur performances and recreation of the workers.

So, having analyzed the development of the leisure activity sphere in the 20-30ies of the XXth century it is possible to come to the following conclusions. The leisure activity sphere in Ukraine at this period has several disadvantages, namely, the execution by the leisure activity institutions ideological, political and educational functions. Nevertheless the objective estimation of the development of the leisure activity sphere in the 20-30ies of the $X X^{\text {th }}$ century requires the analysis of those positive sides that were achieved. Namely, the soviet government formed such a state system that seized all layers of population. Except existing prerevolutionary institutions of leisure activities (clubs, national houses) there appear new types of institutions: reading-rooms, cultural and educational groups, houses and palaces of culture etc. The state nationalized cultural institutions (museums, galleries, cinemas, national houses), their visiting became free and affordable; the task of the state was to liquidate the illiteracy of the population that seized all layers of the population and mass character; there was established the system of the staff training of the leisure activity institutions; the leisure activity sphere was enriched with new forms and methods of the work.

\section{תimepamypa}

1. Клубное самоуправление // Клубная работа. Практическая энциклопедия для переподготовки клубных работников. 1926. - Вып.6. - М. :Пролеткульт. - 33 с.

2. Никитина Г. История культурно-досуговой детельности / Г. Никитина. - М. : МГИК, 1998. -65 с.

3. Пиналов С. История культурно-просветительной работы в СССР / С. А. Пиналов, Г. И. Чернявский, А. П. Виноградов. - К. :Вища школа, 1983. - 263 с.

4. Рабочий клуб, его задачи и основная установка // Клубная работа. Практическая энциклопедия для перепедготовки клубных работников. - 1926. - Вып. 3. - М. :Пролеткульт. - 32 с.

5. Сенюшкин Ф. Задачи клубной работы / Ф. Сенюшкин. - М.: Изд-во ВЦСПС, 1926. - 40 с.

6. Сірополко С. Історіяосвіти в Україні / С.Сірополко. - Київ: Наукова думка, 2001. - 912 с.

7. Сірополко С. Народна освіта на українських землях і в колоніях / С.Сірополко // Українська культура: лекції за редакцією Дмитра Антоновича. - К.: Либідь, 1993. - С.72-92.

8. Українська радянська енциклопедія: [в 17 т.] / Голов. редкол. : Бажан М.П. (голов. ред.) [та ін.]. - К., 1962. - T.7. -576 c.

\section{References}

1. Club self-management. Club management. The practice encyclopedia for club staff re-qualification. (6th ed.). (1926). Moscow: Proletkult.

2. Nikitina, G. (1998). History of cultural and leisure activity. Moscow: MGIK.

3. Pinalov, S.A., Chernyavskiy, G.I., \& Vinogradov, A.P. (1983). History of cultural and educational work in Soviet Union. Kyiv: Vyshha shkola.

4. An acting club, its tasks and main facility. Club management. The practice encyclopedia for club staff requalification. (3rd ed.). (1926). Moscow: Proletkult.

5. Senyushkin, F. (1926). The tasks of club work. Moscow: VTsSPS publishing house.

6. Siropolko, S. (2001). History of education in Ukraine. Kyiv: Naukova dumka.

7. Siropolko, S. (1993). National education on Ukrainian lands and colonies. Ukrainian culture: the talks edited by Dmytro Antonovych. Kyiv: Lybidj.

8. Bazhan, M.P. (Eds.). (Volume 7). (1962). Ukrainian Soviet encyclopedia: [in 17 volumes]. Kyiv. 